\title{
Studi Perubahan Garis Pantai di Perairan Muara Sungai Kaliboyo, Batang
}

\author{
Novi Henis Zadia*, Hariyadi, Warsito Atmodjo, Muh Yusuf dan Azis Rifai \\ Departemen Oseanografi, Fakultas Perikanan dan Ilmu Kelautan, Universitas Diponegoro \\ Jl. Prof.H.Soedarto S.H, Tembalang,Semarang, Jawa Tengah 50275 Indonesia \\ Email: *noviheniszadia@gmail.com
}

\begin{abstract}
Abstrak
Perairan Muara Sungai Kaliboyo kawasan yang dinamis dan cepat mengalami perubahan garis pantai dan terbentuk spit di mulut sungai. Sedimen di daerah tersebut sering menutup muara sungai, sehingga mengganggu alur layar nelayan. Tujuan dari penelitian ini adalah untuk mengetahui indikasi perubahan garis pantai serta hubungan antara perubahan garis pantai dengan arus sejajar pantai di lokasi penelitian. Metode penelitian menggunakan metode deskriptif, untuk pengambilan sampel menggunakan metode purposive sampling, metode SMB untuk peramalan gelombang dan perhitungan menggunakan rumus empiris untuk validasi pasang surut, arus sejajar pantai dan parameter akresi-erosi. Hasil penelitian menunjukkan Perairan Muara Sungai Kaliboyo mengalami akresi, hal ini dapat diketahui dari nilai parameter akresi-erosi di tiga penampang. Penampang 1 dengan nilai Go sebesar 0,62, penampang 2 dengan nilai Go sebesar 0,39 dan penampang 3 dengan nilai Go sebesar 0,56. Nilai Go di atas 0,111 menunjukkan adanya akresi. Gelombang datang dari arah Timur Laut menuju Barat Daya menimbulkan gelombang pecah dengan tinggi 0,28 meter pada kedalaman 0,90 meter sehingga membentuk sudut gelombang pecah $(\alpha b)$ sebesar $9,51^{\circ}$. Gelombang pecah tersebut menimbulkan arus sejajar pantai dari Timur ke Barat dengan kecepatan $0,42 \mathrm{~m} / \mathrm{dt}$ yang mengangkut sedimen sejajar pantai, sehingga membentuk spit di muara sungai dari arah Timur memanjang ke Barat.
\end{abstract}

Kata kunci : Arus Sejajar Pantai, Perubahan Garis Pantai, Sungai Kaliboyo,

\section{Abstract}

\section{Study of Shoreline Changes in Kaliboyo River Estuary, Batang}

Kaliboyo River Estuary is a dynamic and rapidly changing area of the coastline and spits are formed at the river mouth. Sediment in this area often closes river mouths, disrupting the flow of fishermen's screens and clogging up river flow which sometimes causes floods around the river mouth. The purpose of this study is to find out indications of shoreline changes and the relationship between shoreline changes with longshore currents at the study site. The research method uses descriptive method, for sampling using purposive sampling method, SMB method for wave forecasting and calculations using empirical formulas. The research method uses descriptive method, for sampling using purposive sampling method, SMB method for wave forecasting and calculations using empirical formulas for tide validation, longshore currents and erosion-accretion parameters. The results showed that Kaliboyo River Estuary had accretion, this can be seen from the value of the erosionaccretion parameter in three cross sections. The first cross section with a Go value of 0,62, second cross section with a Go value of 0,39 and third cross section with a Go value of 0,56. Go values above 0,111 indicate accretion. Waves coming from the Northeast to the Southwest cause a breaking wave with a height of 0,28 meters at 0,90 meters depth to form an angle of breaking wave ( $\alpha b)$ of $9.51^{\circ}$. The breaking wave caused a longshore current from East to West with a speed of $0,42 \mathrm{~m} / \mathrm{sec}$ which transported sediment along the coast, thus forming a spit at the river mouth from the east extending to the west.

Keywords : Kaliboyo River, Longshore Current, Shoreline Change,

\section{PENDAHULUAN}

Kabupaten Batang berbatasan langsung dengan Laut Utara Jawa di sebelah utara. Panjang garis pantai di Kabupaten Batang sendiri pada tahun 2016 mencapai 38,75 kilometer, garis pantai ini dinilai memiliki potensi pemanfaatan lahan yang bagus. Namun, di samping potensi pembangunan yang bagus, juga terdapat masalah berkaitan dengan fenomena oseanografi yang memberi dampak pada masyarakat pesisir. Berdasarkan RTRW Kabupaten Batang Tahun 2011, Kabupaten Batang 
mempunyai kawasan rawan abrasi laut, salah satunya berada di Desa Kedung Segog. Selain itu, di permukiman nelayan kawasan Pantai Batang juga rawan banjir akibat gelombang pasang (Rencana Pembangunan Jangka Menengah Kabupaten Batang, 2018). Perairan Muara Sungai Kaliboyo terletak di Desa Kedungsegog, Kecamatan Tulis, Kabupaten Batang dan berbatasan langsung dengan Laut Jawa. Muara sungai ini memisahkan Dusun Roban Barat di Desa Kedungsegog dan Dusun Roban Timur di Desa Sengon. Terdapat aktivitas masyarakat seperti pemukiman penduduk, pertambakan, pelelangan ikan, penangkapan ikan, dan pariwisata yang berpusat di muara sungai dan pantai sekitarnya. Hal tersebut menjadikan Perairan Muara Sungai Kaliboyo kawasan yang dinamis dan cepat mengalami perubahan garis pantai. Perubahan garis pantai yang terjadi di perairan Muara Sungai Kaliboyo ini diketahui dari adanya sedimentasi di garis pantai hingga terbentuk spit di mulut sungai. Sedimen di daerah tersebut sering menutup muara sungai, sehingga mengganggu alur layar nelayan dan menyumbat aliran air sungai yang terkadang menimbulkan banjir di sekitar mulut sungai (Hariadi, 2006). Tujuan dari penelitian ini adalah untuk mengetahui indikasi perubahan garis pantai serta hubungan antara perubahan garis pantai dengan arus sejajar pantai di lokasi penelitian.

\section{MATERI DAN METODE}

Penelitian dilaksanakan di Perairan Muara Sungai Kaliboyo, Desa Kedungsegog, Kecamatan Tulis, Kabupaten Batang. Peta lokasi penelitian dan pengambilan data sedimen dasar perairan, data angin, data pasang surut serta data gelombang ditunjukkan pada (Gambar 1). Penelitian ini menggunakan data utama meliputi kondisi perairan pantai, data angin, gelombang dan sedimen dasar, serta data penunjang berupa data pasang surut, batimetri dan peta RBI dari BIG. Data angin yang digunakan diperoleh dari situs ECMWF (European Centre for Medium-Range Weather Forecasts) selama 11 tahun dari tahun 2008 hingga 2018. Data pasang surut selama Bulan September 2018 diperoleh dari peramalan pasang surut BMKG (Badan Meteorologi dan Klimatologi Geofisika) Semarang. Sampel sedimen dasar diambil di 48 stasiun, 3 stasiun di muara sungai dan 45 staisun di perairan laut yang mewakili perairan sekitar lokasi penelitian. Metode pengolahan data dilakukan dengan beberapa tahapan yaitu pengolahan data pasang surut menggunakan metode Admiralty, pengolahan data angin menggunakan aplikasi WRPlot, peramalan gelombang metode SMB, validasi data gelombang menggunakan metode RMSE, peta bathimetri menggunakan ArcGIS, kecepatan arus sejajar pantai dan perubahan garis pantai menggunakan rumus parameter akresi-erosi. Untuk menghitung parameter akresi dan erosi dapat dihitung menggunakan rumus sebagai berikut (CERC, 1984) :

$$
\mathrm{Go}=\mathrm{H}_{0} / \mathrm{L}_{0}(\operatorname{Tg} \alpha)^{0,27}\left(\mathrm{D}_{50} / \mathrm{L}_{0}\right)^{-0,67}
$$

dengan Go adalah parameter tanpa dimensi untuk menentukan akresi dan erosi. Pantai dikategorikan dalam bentuk abrasi, akresi atau mengalami keseimbangan dengan cara memasukkan nilai Go yang telah di dapatkan ke dalam kategori di bawah ini :

a. Jika Go $<0,0556$ maka pantai di katakan sedang mengalami abrasi;

b. Jika Go >0,111 maka pantai di katakan sedang mengalami akresi.

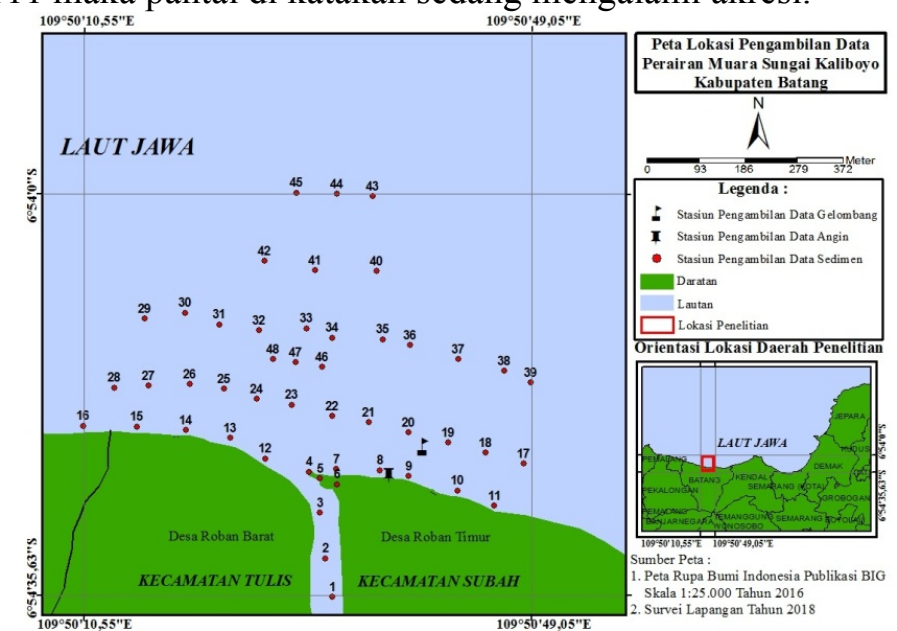

Gambar 1. Peta Lokasi Penelitian dan Pengambilan Sampel. 


\section{HASIL DAN PEMBAHASAN}

Pasang surut di Perairan Muara Sungai Kaliboyo termasuk tipe campuran condong ke harian ganda. Hal tersebut menunjukkan bahwa dalam satu hari terjadi dua kali pasang dan dua kali surut dengan tinggi dan periode yang berbeda. Nilai muka air laut rerata (MSL) bulan September 2018 sebesar 0,62 meter, LLWL sebesar 0,13 meter dan HHWL sebesar 1,26 meter. Berdasarkan hasil pengukuran batimetri dari Perairan Muara Sungai Kaliboyo menunjukkan bahwa kedalaman mulai pantai elevasi 0 meter sampai kedalaman 6 meter pada jarak sekitar 1.200 meter hingga 1.600 meter dari pantai. Kondisi pola batimetri Perairan Muara Sungai Kaliboyo menunjukkan bahwa pola kontur relatif sejajar garis pantai (Gambar 2). Hasil dari perhitungan kemiringan pantai (m) diketahui kemiringan penampang 1 (A-A') sebesar 0,0045, kemiringan penampang 2 (B-B') sebesar 0,0039, serta kemiringan penampang $3\left(\mathrm{C}^{-} \mathrm{C}^{\prime}\right)$ sebesar 0,0040. Menurut Van Zuidam (1985) dalam Arifiyanti (2011) kemiringan pantai pada lokasi penelitian termasuk datar. Penampang melintang batimetri ini digunakan untuk perhitungan kemiringan pantai yang ditunjukkan pada (Gambar 3).

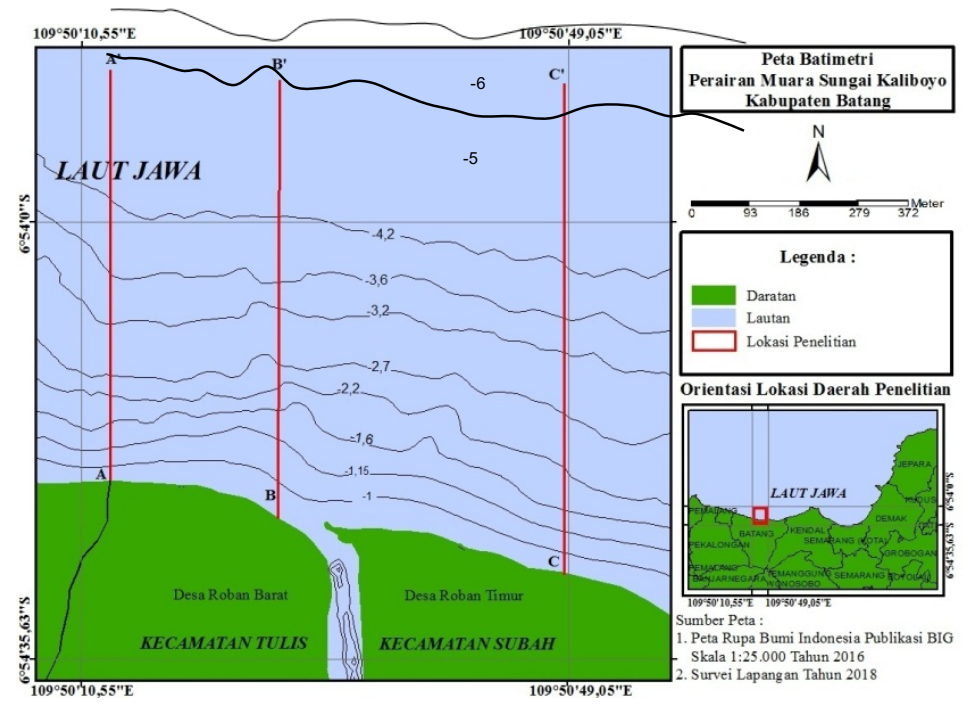

Gambar 2. Peta Batimetri di Perairan Muara Sungai Kaliboyo.
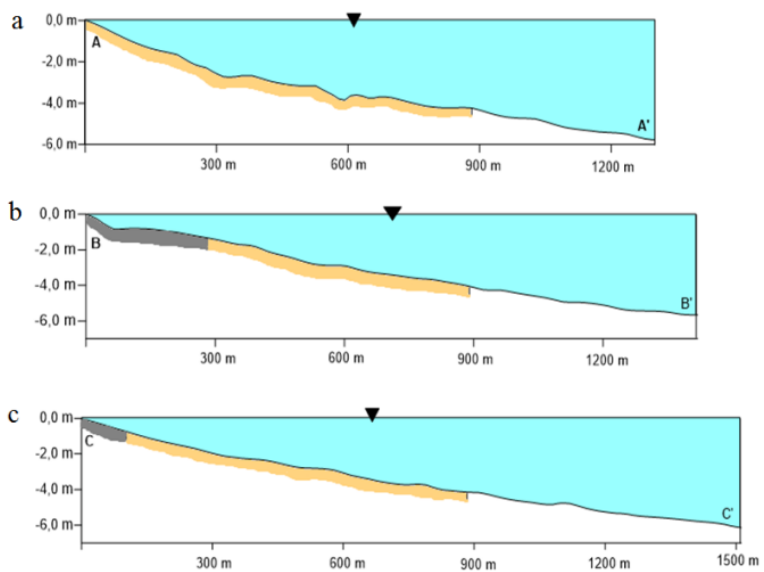

Gambar 3. Penampang Melintang Batimetri a) Penampang 1, b) Penampang 2, c) Penampang 3.

Sedimen di lokasi penelitian terbagi menjadi pasir sedang $(0,5-0,25 \mathrm{~mm})$, pasir halus $(0,25-$ $0,125 \mathrm{~mm})$ dan pasir sangat halus $(0,125 \mathrm{~mm}-0,0625 \mathrm{~mm})$. Stasiun 1,2 dan 3 merupakan lokasi pengambilan sedimen dasar di muara sungai. Hasil sedimen dasar di muara sungai berupa pasir sangat halus. Stasiun 4, 5 dan 6 merupakan lokasi pengambilan sedimen di spit. Hasil sedimen di spit berupa pasir halus hingga pasir sedang. Stasiun 7 hingga 48 merupakan lokasi pengambilan sedimen dasar di 
perairan laut. Hasil sedimen dasar di perairan laut berupa pasir halus hingga pasir sedang. Sebaran sedimen dasar perairan ditunjukkan pada (Gambar 4).

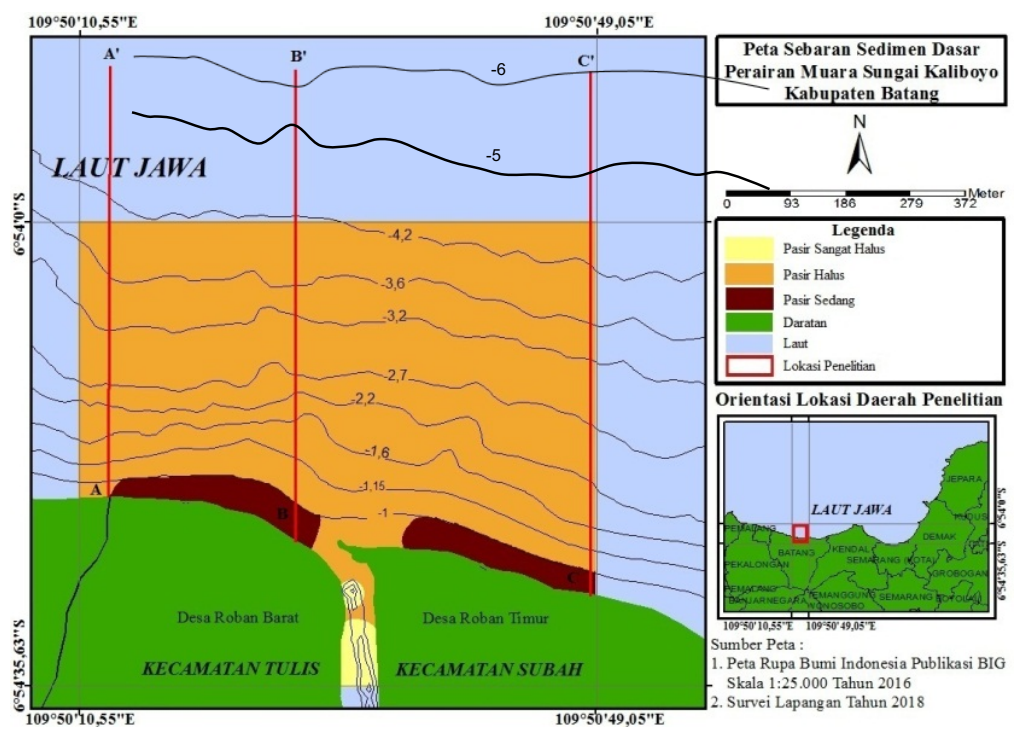

Gambar 4. Peta Sebaran Sedimen.

Pantai di perairan ini termasuk ke dalam pantai berpasir dibuktikan dengan sedimen yang dominan berdiameter 0,10 hingga $0,42 \mathrm{~mm}$ yang termasuk dalam jenis pasir sangat halus - pasir sedang. Ukuran butir merupakan indikasi besar/kuatnya kekuatan arus dan gelombang yang bekerja pada lingkungan pengendapan (Gemilang, 2017). Adanya sedimen berukuran kasar dalam hal ini adalah pasir menunjukkan bahwa arus dan gelombang pada lokasi penelitian relatif kuat.

Muara sungai di perairan ini termasuk dalam muara sungai yang didominasi oleh energi gelombang dilihat dari energi dominan yang berpengaruh terhadap transpor sedimen dan sebaran jenis sedimen di perairan tersebut. Sedimen pada muara sungai berjenis pasir sangat halus, kemudian sedimen pada spit berjenis pasir halus hingga pasir sedang, sedangkan di perairan laut sedimennya berjenis pasir sedang di stasiun yang dekat dengan garis pantai dan dominasi jenis pasir halus hingga lepas pantai. Hal ini sesuai dengan pernyataan Siddiqui et al., (2017) bahwa pada muara yang didominasi oleh gelombang, sedimen yang lebih kasar memiliki kecenderungan untuk terkonsentrasi di pantai dan sedimen halus bergeser ke lepas pantai. Selain itu, pada muara sungai terbentuk spit dengan dominan sedimen jenis pasir halus. Spit ini biasanya berkembang pada daerah dengan dominasi gelombang. Hal tersebut diperkuat oleh pernyataan Randazzo et al., (2015) yang menyatakan bahwa gelombang dengan periode pendek yang mendekati pantai dengan sudut yang tinggi merupakan salah satu gelombang yang dominan dalam pembentukan spit.

Berdasarkan skala Beaufort, angin yang terjadi di lokasi penelitian termasuk ke dalam angin agak kencang dengan kecepatan 1,6 - 3,3 m/dt. Arah angin pada Musim Barat dan Musim Peralihan 1 dominan berasal dari Selatan Barat Daya dengan arah N 202,5 E menuju Utara Timur Laut dengan kecepatan angin dominan yaitu 1,6 - 3,3 m/dt. Arah angin pada Musim Timur dan Peralihan 2 dominan berasal dari Timur Laut dengan arah $\mathrm{N} 45^{\circ}$ E menuju Barat Daya dengan kecepatan angin dominan yaitu 1,6 - 3,3 m/dt. Mawar angin berdasarkan musim ditunjukkan pada (Gambar 5). Data angin tersebut digunakan untuk menentukan arah fetch. Dilihat dari arah fetch efektif, arah gelombang dominan yang berpengaruh terhadap sedimentasi di lokasi penelitian berasal dari arah Timur Laut menuju Barat Daya $\left(\mathrm{N} 45^{\circ}\right)$ dengan fetch sepanjang 8,61 kilometer.

Peramalan gelombang laut menggunakan data arah dan kecepatan angin selama waktu pengamatan. Peramalan dengan metode SMB menghasilkan tinggi dan periode gelombang maksimum, signifikan, serta minimum. Hasil peramalan tersebut ditunjukkan pada Tabel. 1. Tinggi dan periode gelombang representatif hasil dari peramalan gelombang permusim selama 11 tahun ditunjukkan pada Tabel 2.Setelah dilakukan peramalan gelombang, hasil dari peramalan tersebut divalidasi dengan data 
pengukuran di lapangan. Perbandingan data tinggi dan periode gelombang signifikan hasil peramalan dengan data lapangan ditunjukkan pada Tabel 3.

a

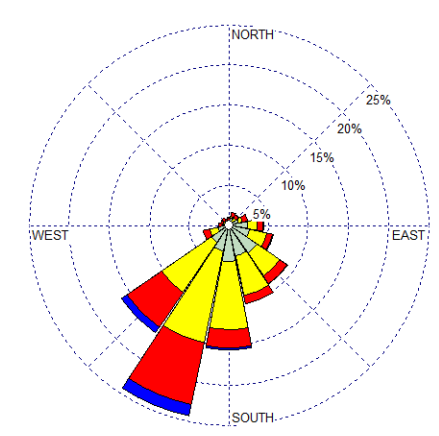

$\mathrm{c}$

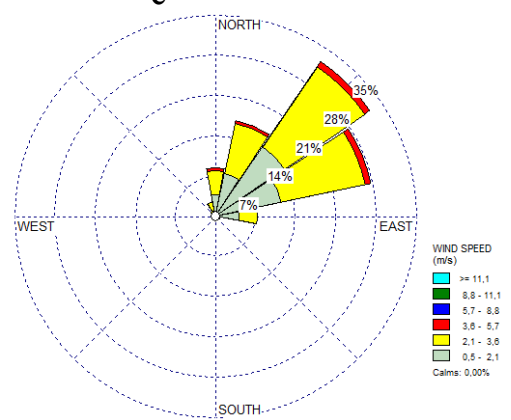

b

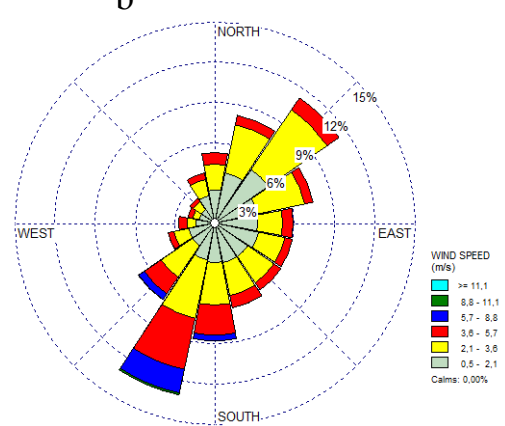

d

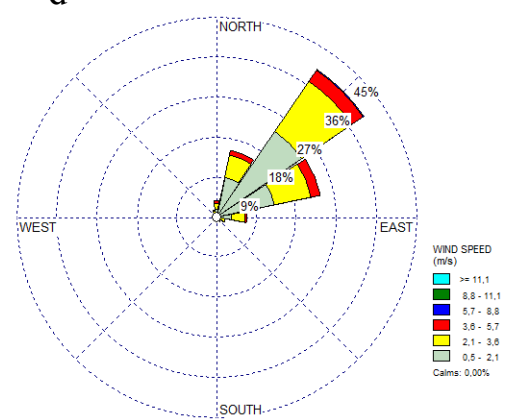

Gambar 5. a) Musim Barat, b) Musim Peralihan 1, c) Musim Timur, d) Musim Peralihan 2.

Tabel 1. Tinggi dan Periode Gelombang Data Lapangan

\begin{tabular}{ccccc}
\hline No & Tanggal & Keterangan & Tinggi (m) & Periode (dt) \\
\hline 1. & $13-15$ & Maksimum & 1,97 & 2,46 \\
2. & September & Signifikan & 1,82 & 2,23 \\
3. & 2018 & Minimum & 0,31 & 0,21 \\
\hline
\end{tabular}

Tabel 2. Periode dan Tinggi Gelombang Hasil Peramalan Permusim

\begin{tabular}{cccccccc}
\hline \multirow{3}{*}{ Musim } & \multicolumn{3}{c}{ Periode Gelombang } & \multicolumn{3}{c}{ Tinggi Gelombang } & \multirow{2}{*}{ Arah } \\
\cline { 2 - 6 } & T Min & T Sig & T Mak & H Min & H Sig & H Mak & (N..E) \\
& (dt) & (dt) & $\mathbf{( d t )}$ & $\mathbf{( m )}$ & $\mathbf{( m )}$ & $\mathbf{( m )}$ & \\
\hline Timur & 0,40 & 2,55 & 9,99 & 0,14 & 0,50 & 1,52 & $225^{\circ}$ \\
Peralihan 2 & 0,07 & 2,75 & 6,68 & 0,04 & 0,57 & 1,13 & $225^{\circ}$ \\
\hline
\end{tabular}

Tabel 3. Perbandingan Tinggi dan Periode Gelombang Signifikan Antara Gelombang Peramalan dengan Gelombang Lapangan menggunakan data Angin

\begin{tabular}{cccc}
\hline No & Keterangan & H Signifikan $(\mathbf{m})$ & T Signifikan (dt) \\
\hline 1. & Data Lapangan & 1,73 & 2,10 \\
2. & Data Peramalan & 1,82 & 2,23 \\
\hline
\end{tabular}


Data hasil peramalan divalidasi dengan data lapangan menggunakan metode RMSE. Hasil validasi tersebut ditunjukkan pada Tabel 4.

Tabel 4. Perbandingan Validasi Tinggi Gelombang Signifikan antara Gelombang Peramalan dengan Pengukuran

\begin{tabular}{cccc}
\hline No & Data & Tinggi Gelombang Signifikan (m) & Nilai Error \\
\hline 1. & Lapangan & 0,160 & 0,049 \\
2. & Peramalan & 0,111 & \\
\hline
\end{tabular}

Dari data di atas, diketahui nilai validasi tinggi gelombang signifikan (Hs) antara data lapangan dengan data peramalan sebesar 0,049 . Nilai tersebut kurang dari 1 yang menunjukkan bahwa data hasil peramalan dapat dikategorikan data yang bagus dan dapat digunakan untuk perhitungan berikutnya.

Perhitungan gelombang reperesentatif tiap musim menghasil nilai tinggi gelombang pecah $\left(\mathrm{H}_{\mathrm{b}}\right)$, kedalaman gelombang pecah $\left(\mathrm{d}_{\mathrm{b}}\right)$ dan sudut gelombang pecah $\left(\alpha_{\mathrm{b}}\right)$ yang disajikan dalam Tabel 5 .

Tabel 5. Perhitungan Tinggi, Kedalaman dan Sudut Gelombang Pecah

\begin{tabular}{ccccccc}
\hline Musim & $\mathbf{H}_{\mathbf{s}}(\mathbf{m})$ & $\mathbf{T}_{\mathbf{s}} \mathbf{( d t )}$ & $\boldsymbol{\alpha}_{\mathbf{0}}\left(^{\circ}\right)$ & $\mathbf{H}_{\mathbf{b}}(\mathbf{m})$ & $\mathbf{d}_{\mathbf{b}}(\mathbf{m})$ & $\boldsymbol{\alpha}_{\mathbf{b}}\left(^{\circ}\right)$ \\
\hline Timur & 0,50 & 2,55 & 35 & 0,44 & 0,25 & 9,69 \\
Peralihan 2 & 0,57 & 2,75 & 35 & 0,90 & 0,28 & 9,51 \\
\hline
\end{tabular}

Berdasarkan kedalaman relatif, gelombang di Perairan Muara Sungai Kaliboyo termasuk dalam gelombang laut dalam. Nilai tinggi gelombang pecah pada Musim Peralihan 2 lebih besar dibanding Musim Timur. Hal ini sesuai dengan pernyataan CERC (1984) yang menyatakan bahwa variabel yang paling penting dalam menentukan kecepatan arus sejajar pantai adalah tinggi gelombang pecah dan sudut antara gelombang pecah dengan garis pantai. Arus sejajar pantai terjadi ketika gelombang pecah datang menuju pantai dan membentuk sudut lebih dari $5^{\circ}$ terhadap garis pantai (Triatmodjo, 1999). Arus sejajar pantai ini dapat mengangkut sedimen sepanjang pantai yang disebut longshore sediment transport. Transpor sedimen tersebut merupakan penyebab utama perubahan garis pantai.

Nilai kecepatan arus sejajar pantai tiap musim dan arahnya dapat dilihat pada (Tabel 6). Ilustrasi pergerakan arus sejajar pantai pada Musim Timur dan Musim Peralihan 2 dapat dilihat pada (Gambar 6).

Tabel 6. Hasil Perhitungan Kecepatan Arus Sejajar Pantai Permusim

\begin{tabular}{llll}
\hline Musim & $\begin{array}{l}\text { Arus Sejajar } \\
\text { Pantai (m/dt) }\end{array}$ & Arah $\left(\mathbf{N}^{\circ} \mathbf{E}\right)$ & dari arah - ke arah \\
\hline Musim Timur & 0,39 & 99,69 & Timur - Barat \\
Musim Peralihan 2 & 0,42 & 99,51 & Timur - Barat \\
\hline
\end{tabular}

Perubahan garis pantai pada Perairan Muara Sungai Kaliboyo dari tahun 2014 hingga 2018 dapat dilihat pada (Gambar 7), terlihat bahwa garis pantai mengalami penambahan atau akresi. Pada tahun 2018 terlihat bahwa garis pantai lebih menjorok ke laut, selain itu juga terbentuk spit di mulut sungai. Pada penelitian ini digunakan parameter akresi-erosi (Go) untuk mengetahui indikasi perubahan garis pantai. Perhitungan parameter akresi-erosi dilakukan pada tiga penampang melintang batimetri. Satu penampang di sebelah timur yatu penampang 3 dan dua penampang di sebelah barat yaitu penampang 1 dan 2. Hasil perhitungan parameter akresi-erosi ditunjukkan pada Tabel 7. 


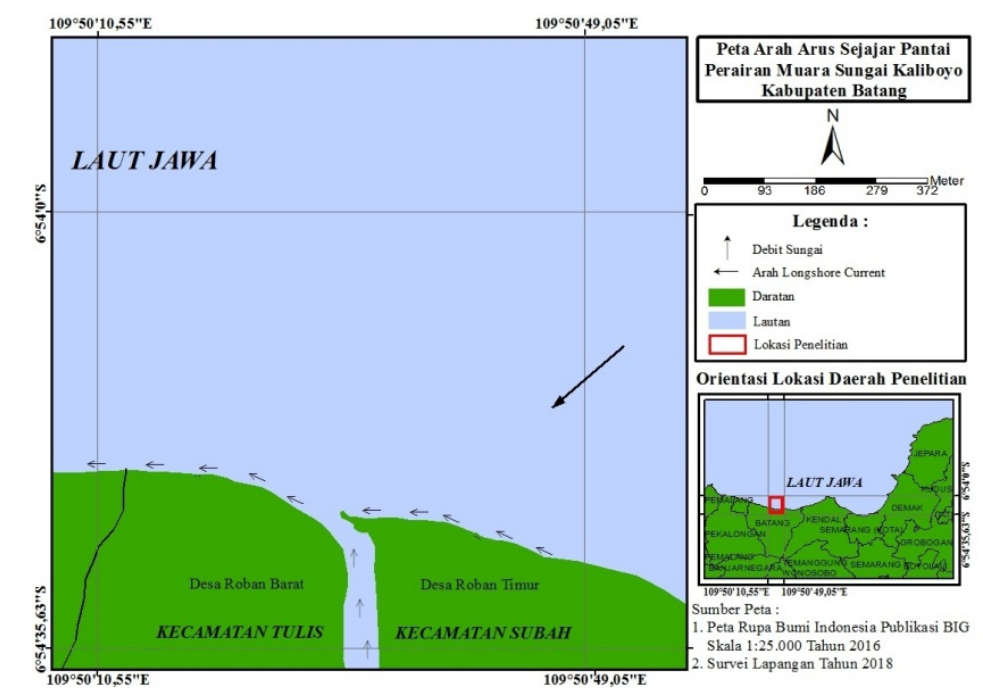

Gambar 6. Arah Arus Sejajar Pantai Semua Musim.

Tabel7. Hasil Perhitungan Parameter Akresi Erosi

\begin{tabular}{ccccc}
\hline Musim & Penampang & $\begin{array}{c}\text { Angkutan Sedimen } \\
\text { Perdetik (Qs) }\end{array}$ & Nilai Go & Indikasi \\
\hline Musim Timur & $1\left(\mathrm{~A}-\mathrm{A}^{\prime}\right)$ & 0,0024 & 0,62 & Akresi \\
Musim Timur & $2\left(\mathrm{~B}-\mathrm{B}^{\prime}\right)$ & 0,0024 & 0,39 & Akresi \\
Musim Timur & $3\left(\mathrm{C}-\mathrm{C}^{\prime}\right)$ & 0,0024 & 0,56 & Akresi \\
\hline
\end{tabular}

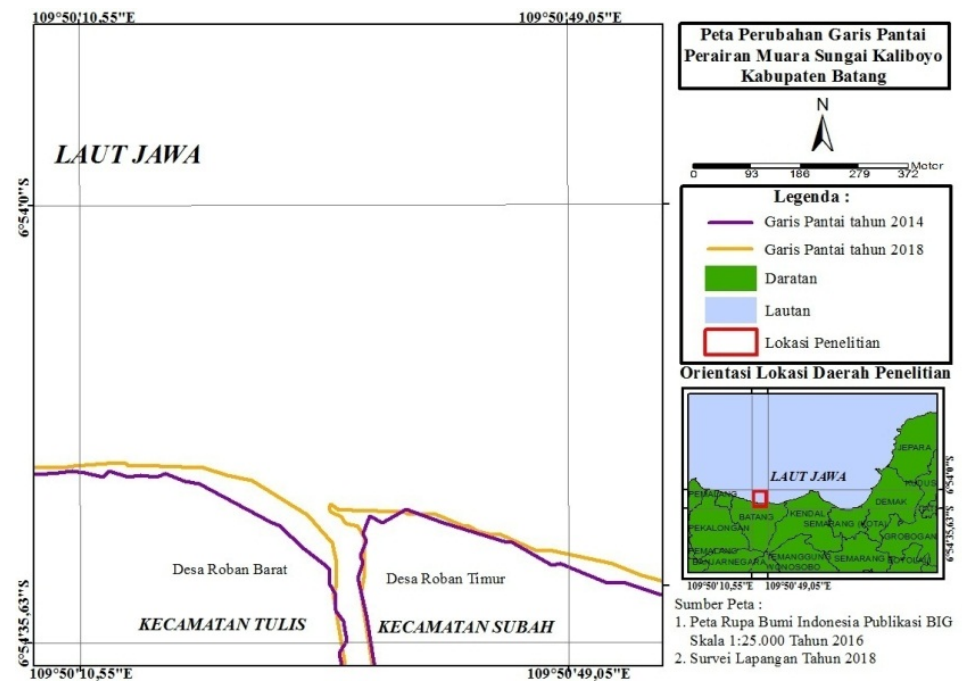

Gambar 7. Perubahan Garis Pantai 2014-2018.

Berdasarkan uraian di atas, dapat disimpulkan bahwa angin pada Musim Peralihan 2 berhembus dari Timur Laut menuju Barat Daya dengan kecepatan 1,6 - 3,3 m/dt , kemudian membangkitkan gelombang dengan arah yang sama. Kemudian angin tersebut membangkitkan gelombang di perairan bergerak menuju Barat Daya. Gelombang yang datang menuju pantai kemudian pecah akibat pendangkalan. Gelombang pecah dengan tinggi 0,28 meter pada kedalaman 0,90 meter sehingga membentuk sudut gelombang pecah $(\alpha b)$ sebesar $9,51^{\circ}$. Gelombang pecah tersebut kemudian 
menimbulkan arus sejajar pantai dengan kecepatan $0,42 \mathrm{~m} / \mathrm{dt}$ dari arah Timur ke Barat yang dapat mengangkut sedimen sepanjang garis pantai. Kemudian sedimen tersebut terendapkan pada garis pantai terus menerus hingga membentuk spit yang membentang dari Timur ke Barat hingga hampir menutup mulut sungai. Gelombang yang terjadi di pantai berpasir dapat menimbulkan angkutan sedimen dalam arah tegak lurus maupun sejajar garis pantai. Apabila debit sungai kecil dan kecepatan arusnya tidak dapat mengerosi endapan tersebut sehingga muara sungai dapat tertutup oleh sedimen tersebut karena di daerah tersebut kondisi gelombang sudah tenang maka sedimen akan mengendap. Semakin besar gelombang semakin besar angkutan sedimen dan semakin banyak sedimen yang mengendap di muara (Pangestu, 2013). Pengendapan sedimen di muara secara terus-menerus dapat mengakibatkan pendangkalan pada muara. Sedimentasi ini juga dapat mengakibatkan perubahan garis pantai berupa penambahan (akresi). Bahkan dapat membentuk sebuah penghalang seperti spit seperti yang terjadi di lokasi penelitian.

\section{KESIMPULAN}

Perairan Muara Sungai Kaliboyo mengalami akresi. Nilai Go di atas 0,111 menunjukkan adanya akresi. Gelombang datang dari arah Timur Laut menuju Barat Daya menimbulkan gelombang pecah dengan tinggi 0,28 meter pada kedalaman 0,90 meter sehingga membentuk sudut gelombang pecah $(\alpha b)$ sebesar $9,51^{\circ}$. Gelombang pecah tersebut menimbulkan arus sejajar pantai dari Timur ke Barat dengan kecepatan $0,42 \mathrm{~m} / \mathrm{dt}$ yang mengangkut sedimen sejajar pantai, sehingga membentuk spit di muara sungai dari arah Timur memanjang ke Barat.

\section{DAFTAR PUSTAKA}

Arifianti, Y. 2011. Potensi Longsor Dasar Laut di Perairan Maumere. Bulletin Vulkanologi dan Bencana Geologi, 6(1): $53-62$.

CERC. 1984. Shore Protection Manual Volume I. US Army Coastal Engineering Research Center, Washington.

Gemilang, Wisnu A., Ulung J. Wisha, Guntur A. Rahmawan dan Ruzana Dhiauddin. 2017. Karakteristik Sebaran Sedimen Pantai Utara Jawa Studi Kasus: Kecamatan Brebes Jawa Tengah. Jurnal Kelautan Nasional, 13(2):65-74.

Pangestu, Hendar. 2013. Analisis Angkutan Sedimen Total Pada Sungai Dawas Kabupaten Musi Banyuasin. Jurnal Teknil Sipil dan Lingkungan, 1(1):103-9.

Randazzo, Giovanni, Derek W. T. Jackson and J. Andrew G. Cooper. 2015. Sand and Gravel Spits. Springer. Coastal Research Library 12.

Rencana Pembangunan Jangka Menengah Kabupaten Batang, 2018. Pemerintah Kabupaten Batang, Jawa Tengah.

Siddiqui et al., 2017. Shallow-marine Sandstone Reservoirs, Depositional Environments, Stratigraphic Characteristics and Facies Model: A Review. Journal of Applied Science.

Triatmodjo, Bambang. 1999. Teknik Pantai. Beta Offset, Yogyakarta. 